\title{
Comparison of Two Different Methods for Measurement of Amyloid- $\beta$ Peptides in Cerebrospinal Fluid after BACE1 Inhibition in a Dog Model
}

\author{
Herman Borghys*, Tom Jacobs, Bianca Van Broeck, Lieve Dillen, Deborah Dhuyvetter, \\ Harrie Gijsen and Marc Mercken \\ Janssen Research \& Development, Pharmaceutical Companies of Johnson \& Johnson, Beerse, Belgium
}

Handling Associate Editor: Erik Portelius

Accepted 12 June 2013

\begin{abstract}
Beta-secretase is the first cleavage enzyme of amyloid- $\beta$ protein precursor (A $\beta P P)$ in the amyloidogenic pathway, leading to the formation of the plaque forming Amyloid- $\beta(\mathrm{A} \beta)_{1-42}$ peptide. BACE (beta-site A $\beta P P$ cleaving enzyme) 1 inhibition is therefore considered to be a promising disease modifying therapy for Alzheimer's disease. An early assessment of the in vivo activity of BACE inhibitors was done in dogs since AßPP processing is the same as in humans and this species easily enables longitudinal cerebrospinal fluid (CSF) sampling. A $\beta$ changes in CSF compared to baseline are used to evaluate target engagement of the compounds. Levels of $A \beta_{1-37}, A \beta_{1-38}, A \beta_{1-40}$, and $A \beta_{1-42}$ in CSF are measured with immunoassay (Mesoscale electrochemiluminescence technology) and with an ultra high-performance liquid chromatography mass spectrometry (UPLCMS/MS). Two experimental BACE inhibitors were evaluated. With the immunoassay, a dose dependent decrease is observed for all four $A \beta$ peptides. Measurements with the UPLC-MS/MS are in line with the immunoassay for $A \beta_{1-37}, A \beta_{1-38}$, and $\mathrm{A} \beta_{1-40}$, however, for $A \beta_{1-42}$, differences are sometimes observed when comparing to changes seen in the other peptides with UPLC-MS/MS and with immunoassay results. Generally lower concentrations are measured with immunoassay. The reason for these differences is still unknown. $A \beta_{1-42}$ is more prone to form aggregates compared to the other peptides. One hypothesis could be that while the immunoassay only measures free $A \beta$, bound and aggregated $A \beta$ peptides are at least partially dissolved with the UPLC-MS/MS method, since acetonitrile is added to the CSF samples. This increases variability in the concentration of $A \beta$ peptide measured with UPLC-MS/MS, especially for $A \beta_{1-42}$, potentially masking the compound effect on $A \beta_{1-42}$ levels.
\end{abstract}

Keywords: Alzheimer's disease, amyloid- $\beta$ peptides, $\beta$-secretase, cerebrospinal fluid, dog

\section{INTRODUCTION}

Amyloid plaques, amorphous and fibrillar deposits of amyloid- $\beta(A \beta)$, are one of the neuropathological hallmarks of Alzheimer's disease [1]. Mainly $A \beta_{1-42}$

*Correspondence to: Herman Borghys, Biomarkers and Translational Pharmacology, Janssen Research \& Development, Turnhoutseweg 30, 2340 Beerse, Belgium. Tel.: +32 146023 79; E-mail: hborghys@its.jnj.com. peptides have the tendency to form soluble oligomers, which precipitate and form plaques [2]. $A \beta_{1-42}$ is a cleavage product of the transmembranous amyloid- $\beta$ protein precursor (A $\beta P P)$ via the $\beta$-secretase pathway. The cleavage by $\beta$-secretase (BACE1) liberates the $A \beta$ N-terminus, together with $\mathrm{AA} \beta \mathrm{PP} \beta$ and a $\mathrm{C}$ terminal fragment C99. C99 is subsequently cleaved by $\gamma$-secretase to yield $A \beta$ and an AICD (Amyloid precursor protein Intracellular Domain) [3]. $\beta$ - as well 
as $\gamma$-secretases are therapeutic targets of interest to lower $A \beta_{1-42}$ via inhibition or modulation by small molecules [4].

The dog presents a good species for assessing the effects of compounds on A $\beta P P$ processing [5]. The association between brain and cerebrospinal fluid (CSF) $A \beta$ with aging is similar to that observed in Alzheimer's disease patients [6]. Dogs develop amyloid plaques [7] and are used as a natural model of age-dependent cognitive dysfunction [8]. There is a high level of homology between human and canine A $\beta P P$ isoforms and the proteases implicated in their amyloidogenic and non-amyloidogenic processing as well as enzymes implicated in A $\beta$ degradation [9]. The $\mathrm{A} \beta$ isoform pattern in CSF of dogs resembles that in humans [10] and the turnover of $A \beta$ in the CSF is comparable between dog and humans [11].

Different assays are used to measure $A \beta$ peptides in dog CSF. Immunoassays [6, 12], ultra highperformance liquid chromatography mass spectrometry (UPLC-MS/MS) [13], immunoprecipitation mass spectrometry (IP-MS) [10], and peptide adsorptioncontrolled liquid chromatography-tandem mass spectrometry (PAC-LC-MS/MS) [14] are described. Sampling and processing procedures of CSF samples have a big impact on the outcome of the analysis [15].

We use the dog as a preclinical species to evaluate the effect of BACE inhibitors in vivo [16]. The effects on $A \beta_{1-37}, A \beta_{1-38}, A \beta_{1-40}$, and $A \beta_{1-42}$ in CSF are measured with immunoassay (Mesoscale electrochemiluminescence technology) and with UPLC-MS/MS. Both methods will be compared and discussed.

\section{MATERIALS AND METHODS}

\section{Test compounds}

JNJ-A and JNJ-B are in house synthesized BACE1inhibitors as patented in WO-2011/154431 [17].

\section{Experimental designs}

Spread over five separate single dose studies (studies 1-5), JNJ-A [10 (study 1), 0.31 and 2.5 (study 2), and 0.08 and $0.16 \mathrm{mg} / \mathrm{kg}$ (study 3)] and JNJ-B [2.5 and 10 (study 4) and $1.25,5$, and $20 \mathrm{mg} / \mathrm{kg}$ (study 5)], both formulated as $20 \%$ hydroxypropyl- $\beta$ cyclodextrin solutions, were administered to male and female beagle dogs, aged 3-6 years. A vehicle group ( $20 \%$ hydroxypropyl- $\beta$-cyclodextrin, $1-4 \mathrm{ml} / \mathrm{kg}$ ), was included in each study. Dosing volume was $1 \mathrm{ml} / \mathrm{kg}$ except for the $10 \mathrm{mg} / \mathrm{kg}$ dose of JNJ-A ( $4 \mathrm{ml} / \mathrm{kg}$ ) and the 10 and $20 \mathrm{mg} / \mathrm{kg}$ dose of JNJ-B ( 2 and $4 \mathrm{ml} / \mathrm{kg}$ respectively). Animals were randomly selected from our colony for each study separately. Two male and 2 female beagle dogs were included per dosage group, with exception of 3 males and 3 females for the 2.5 and $10 \mathrm{mg} / \mathrm{kg}$ dose of JNJ-B and the corresponding vehicle group in the study.

Animals were dosed orally via a gastric tube on an empty stomach. CSF was sampled in conscious dogs from the lateral ventricle [5, 18] before dosing and at 8 and $25 \mathrm{~h}$ after dosing. Per time-point $400 \mu \mathrm{l}$ CSF per dog was sampled in a polypropylene micronic tube, gently mixed and divided in different aliquots for $\mathrm{A} \beta$ measurements, placed immediately on dry ice and stored at $-80^{\circ} \mathrm{C}$. Two aliquots of $150 \mu$ l were used for UPLC-MS/MS and one aliquot of $100 \mu \mathrm{l}$ was used for Mesoscale.

Plasma samples for drug exposure were taken at 0.5 , $1,2,4,8$, and $24 \mathrm{~h}$ after dosing. Blood was sampled in EDTA tubes, protected from light, centrifuged and per sample $200 \mu \mathrm{l}$ plasma was stored at $-20^{\circ} \mathrm{C}$ until analysis.

Baseline data of $A \beta$ in CSF of the cisterna magna are used from other studies. CSF sampling from the cisterna magna was performed under short general intravenous anesthesia $[0.2 \mathrm{ml}$ medetomidine (Domitor ${ }^{\circledR}$ ) and $2 \mathrm{ml}$ propofol (Propovet ${ }^{\circledR}$ )].

The studies were approved by the Ethical Committee on Laboratory Animal Testing (ECD, Janssen Beerse).

\section{UPLC-MS/MS method for drug concentrations in canine plasma}

Plasma levels of JNJ-A and JNJ-B were determined using a qualified research LC-MS/MS method.

After protein precipitation (with acetonitrile) plasma samples were quantified on a reversed phase UPLCcolumn (Acquity BEH C $181.7 \mu \mathrm{m}, 2.1 \times 50 \mathrm{~mm}$; Waters). Mobile phases consisted of $0.1 \%$ formic acid (solvent A) and methanol (solvent B). Starting conditions were typically from $70 \%$ solvent $\mathrm{A}$ and $30 \%$ solvent B followed by a linear gradient to $5 \%$ solvent $\mathrm{A}$ and $95 \%$ solvent $\mathrm{B}$ over $1.0 \mathrm{~min}$ followed by an isocratic hold at a flow rate of $0.8 \mathrm{ml} / \mathrm{min}$. For each compound, gradient conditions were optimized and differed slightly.

LC-MS/MS analysis was carried out on an API4000 MS/MS (Applied Biosystems, Toronto, Canada), which was coupled to an UPLC-system (Waters; Milford, US). The MS/MS, operated in the positive ion mode using the TurboIonSpray ${ }^{\mathrm{TM}}$-interface (electro- 
spray ionization), was optimized for the quantification of each compound.

The limit of quantification was at least $5.0 \mathrm{ng} / \mathrm{ml}$ for plasma samples for all analytes. The accuracy (intra batch accuracy from independent QC samples) was between $85 \%$ and $115 \%$ of the nominal value over the entire range for plasma samples

\section{UPLC-MS/MS method for amyloid peptides in canine $C S F$}

The UPLC-MS/MS method for the analysis of amyloid peptides in CSF is described by Dillen et al. [13].

Dog CSF samples were provided in Micronic tubes. CSF sample preparation was performed by adding 1 volume of acetonitrile containing $10 \% \mathrm{NH}_{4} \mathrm{OH}$ to 4 volumes $\mathrm{CSF}$, resulting in final acetonitrile and $\mathrm{NH}_{4} \mathrm{OH}$ concentrations of $20 \%$ and $2 \%$, respectively.

UPLC analysis was performed on an Acquity $300 \AA$ $\mathrm{C}_{18} 1.7 \mu \mathrm{m} 2.1 \times 50 \mathrm{~mm}$ PST column (Peptide Separation Technology; $\mathrm{pH}$ range 1-12, Waters Inc., Milford, USA) at $35^{\circ} \mathrm{C}$. Solvent A consisted of $0.1 \% \mathrm{NH}_{4} \mathrm{OH}$ in water and solvent $\mathrm{B}$ of $0.1 \% \mathrm{NH}_{4} \mathrm{OH}$ in acetonitrile.

Chromatographic separation of the amyloid peptides was obtained at a flow rate of $0.4 \mathrm{~mL} / \mathrm{min}$ under following conditions: $t=0 \mathrm{~min} 99 \%$ solvent $\mathrm{A}$; after an isocratic hold for $0.5 \mathrm{~min}$, a linear gradient to $60 \% \mathrm{~B}$ was generated over $1.5 \mathrm{~min}$ with a further increase to $95 \% \mathrm{~B}$ for $0.3 \mathrm{~min}$ before re-equilibration to the initial conditions.

Electrospray MS/MS analysis was carried out on an API4000 triple quadrupole instrument (Sciex, Toronto, Canada) operated in the negative ion mode. The instrument was optimized for each individual peptide. SRM transitions were as follows: $A \beta_{1-37} \mathrm{~m} / \mathrm{z}$ $1017.6(\mathrm{M}-4 \mathrm{H})^{4-}>1013.2, \mathrm{~A} \beta_{1-38} \mathrm{~m} / \mathrm{z} 1032.1$ (M$4 \mathrm{H})^{4-}>1027.5, \mathrm{~A} \beta_{1-40} \mathrm{~m} / \mathrm{z} 1081.6(\mathrm{M}-4 \mathrm{H})^{4-}>1077$ and $A \beta_{1-42} \mathrm{~m} / \mathrm{z} 1127.6(\mathrm{M}-4 \mathrm{H})^{4-}>1123.2$.

The limit of quantification was $100 \mathrm{pg} / \mathrm{ml}$ for all peptides. The accuracy (intra batch accuracy from independent QC samples) was between $80 \%$ and $120 \%$ of the nominal value over the entire range for the CSF samples. Study samples were analyzed in duplo and mean concentrations were reported.

The levels of each amyloid peptide in canine CSF study samples were expressed in absolute levels and relative to the start sample (predose) of the experiment. In each animal, peak areas obtained in the predose samples are defined as $100 \%$ and all other timepoints are expressed relative (in \%) to the predose sample peak area.
Multiplex immunoassay method for quantification of $A \beta_{1-37 / 38 / 40 \text { and } 42 \text { levels in } C S F}$

Simultaneous specific quantification of human-type $A \beta_{1-37}, A \beta_{1-38}, A \beta_{1-40}$, and $A \beta_{1-42}$ in dog CSF was performed using MesoScale Discovery (MSD)'s electrochemiluminescence detection technology. Standards of human $A \beta_{1-37}, A \beta_{1-38}, A \beta_{1-40}$, and $A \beta_{1-42}$ (Anaspec, San Jose, CA) were dissolved in dimethylsulphoxide (DMSO) at $0.1 \mathrm{mg} / \mathrm{ml}$ and stored at $-80^{\circ} \mathrm{C}$. For use in the assay, peptides were further diluted in casein buffer $(0.1 \%$ casein in PBS) down to $10 \mathrm{pg} / \mathrm{ml}$. Purified monoclonal antibodies specific for $A \beta_{1-37}$ (JRD/A $\beta 37 / 3), \quad A \beta_{1-38}$ (J\&JPRD/A $\left.\beta 38 / 5\right), \quad A \beta_{1-40}$ (JRF/cA $\beta 40 / 28)$, and $A \beta_{1-42}(\mathrm{JRF} / \mathrm{cA} \beta 42 / 26)$ were coated on MSD 4-plex 96-well plates. Plates were blocked with casein buffer $(0.1 \%$ casein in PBS buffer) for $1-4 \mathrm{~h}$ at room temperature. After washing, standards and prediluted samples (1/2 dilution of the samples) were incubated in MSD 4-plex plates (Mesoscale Discovery) overnight at $4^{\circ} \mathrm{C}$ together with SULFO-TAG-labeled human-specific detection antibody JRF/A $\beta N / 25$. The SULFO-TAG emits light upon electrochemical stimulation initiated at the electrode surface of the 4-plex plates. After overnight incubation, plates were washed and assays are developed using 2x Read Buffer (Mesoscale Discovery) according to the manufacturer's recommendations and plates were read on MSD Sector Imager 6000. CSF samples contaminated with blood were not used in the analysis.

All calibration standards and study samples were analyzed in duplicate. The results were averaged and treated as a single value for all further calculations. Only mean values with replicate well CVs of less than or equal to $20.0 \%$ were accepted. Any sample not meeting this criterion was excluded from any further calculation. The lowest limit of quantification, determined as the lowest calibrator concentration for which overall $\mathrm{CV}$ and bias are $\leq 25.0 \%$, is $4.57 \mathrm{pg} / \mathrm{ml}$ for all $\mathrm{A} \beta$-peptides measured.

\section{Statistics}

The amyloid levels at baseline in the cisterna magna and lateral ventricle were compared using a $t$-test. For comparison of the analytical methods, UPLCMS/MS, and immunoassay, a paired $t$-test was used. Both comparisons were done under the assumption of a log-normal distribution. 


\section{PK/PD modeling}

The traditional analysis attempts to link drug plasma concentrations to the maximal decrease of $A \beta$ peptides. However, a delay between plasma concentrations and $A \beta$ peptide levels is typically observed. As such, any in vivo potency estimates obtained in this way are usually biased.

Therefore, a physiologically inspired analysis is proposed. The mechanism of action of the BACE inhibitors is a blockage of formation of the $A \beta$ peptides. Therefore, the data is analyzed using a turnover model [19], which mimics the production and elimination of amyloid in the brain, where CSF A $\beta$ levels are assumed to be a relevant biomarker for $A \beta$ levels in the brain.

$$
\frac{d R_{i j k}}{d t}=k_{i n}\left(1-\frac{I_{\max } C_{p i j k}}{E C_{50 k}+C_{p i j k}}\right)-k_{o u t} R_{i j k}
$$

$\mathrm{R}_{\mathrm{ijk}}$ : A $\beta$-peptide at time $j$ for animal $i$ with compound $k$

$\mathrm{k}_{\text {in }}$ : amyloid production rate

$\mathrm{k}_{\text {out }}$ : amyloid elimination rate

$I_{\text {max }}$ : maximal inhibition (fixed to $100 \%$ for $A \beta_{38}$, $\mathrm{A} \beta_{40}$, and $\mathrm{A} \beta_{42}$ )

$\mathrm{C}_{\mathrm{pijk}}$ : corresponds to the linear interpolation of the plasma concentrations at time $j$ for animal $i$ with compound $k$

$\mathrm{EC}_{50 \mathrm{k}}$ : plasma concentration required for compound $k$ to obtain $50 \%$ inhibition

\section{RESULTS}

\section{Baseline A $\beta$ levels in CSF}

Before dosing, $\mathrm{A} \beta$ levels in CSF are measured to determine the baseline which is used as reference for evaluation of drug effects. Depending on the study, CSF is sampled from the lateral ventricle or cisterna magna. Over the past year, 99 and 48 baseline samples were taken from the lateral ventricle and cisterna magna, respectively.
The absolute concentrations for $A \beta_{1-37}, A \beta_{1-38}$, $A \beta_{1-40}$, and $A \beta_{1-42}$ are listed in Table 1. Absolute concentrations were the highest for $A \beta_{1-40}$, followed by $A \beta_{1-38}$ and $A \beta_{1-42}$. A $\beta_{1-37}$ was the least present. The concentrations measured with UPLC-MS/MS were consistently higher than with Mesoscale $(p<0.0001$ for all peptides). The difference between both assays was positively correlated with the length of the peptide. The ratio UPLC-MS/MS/Mesoscale was highest for $A \beta_{1-42}$. Levels in cisterna magna were approximately two times higher than in the lateral ventricle for both assays $(p<0.0001$ for all peptides).

The correlation between the UPLC-MS/MS and Mesoscale values is shown in Fig. $1 \mathrm{a}$ and $\mathrm{b}$. There was a good correlation between both assays for $A \beta_{1-38}$ and $A \beta_{1-40}\left(r^{2}=0.43\right.$ and 0.35 in the lateral ventricle and 0.58 and 0.57 in the cisterna magna for $A \beta_{1-38}$ and $A \beta_{1-40}$, respectively). $A \beta_{1-37}$ showed a mixed picture since correlation was good in the cisterna magna, but not in the lateral ventricle. Correlation between UPLC-MS/MS and Mesoscale was low for $A \beta_{1-42}$ $\left(\mathrm{r}^{2}<0.20\right)$.

\section{Pharmacokinetics}

Pharmacokinetic parameters are summarized in Table 2. Mean peak plasma levels ranged from 80 to $1460 \mathrm{ng} / \mathrm{ml}$ for JNJ-B (1.25 to $20 \mathrm{mg} / \mathrm{kg})$ and from 13 to $1905 \mathrm{ng} / \mathrm{ml}$ for JNJ-A (0.08 to $10 \mathrm{mg} / \mathrm{kg})$. The increase in plasma exposure was dose proportional for both compounds. T1/2 was approximately five times longer for JNJ-A (23-26 h) than for JNJ-B (4.5-6.6 h).

$$
A \beta_{1-37}, A \beta_{1-38}, A \beta_{1-40} \text {, and } A \beta_{1-42} \text { in } C S F
$$

The effect on A $\beta$ levels in CSF is expressed as \% change from baseline for each study. For both studies, $A \beta_{1-37}, A \beta_{1-38}, A \beta_{1-40}$ and $A \beta_{1-42}$ peptides were measured with LC-MS/MS as well as Mesoscale. Profiles with the values expressed as \% change from baseline are given in Figs. 2 and 3.

$\mathrm{A} \beta$ lowering was seen from a dose of 0.16 and $1.25 \mathrm{mg} / \mathrm{kg}$ onwards for JNJ-A and JNJ-B,

Table 1

Absolute concentrations (pg/ml, mean \pm SDV) and UPLC-MS/MS/Mesoscale ratio (mean) of amyloid peptides in dog CSF (baseline samples, $n=99$ for lateral ventricle and $n=48$ for cisterna magna)

\begin{tabular}{lccccccc}
\hline & \multicolumn{3}{c}{ Lateral ventricle } & & \multicolumn{3}{c}{ Cisterna magna } \\
\cline { 2 - 3 } & UPLC-MS/MS & Mesoscale & Ratio & & UPLC-MS/MS & Mesoscale & Ratio \\
\hline $\mathrm{A} \beta_{1-37}$ & $495 \pm 223$ & $282 \pm 99$ & 1.8 & & $803 \pm 224$ & $497 \pm 135$ & 1.7 \\
$\mathrm{~A} \beta_{1-38}$ & $2487 \pm 767$ & $924 \pm 341$ & 2.8 & & $4307 \pm 1189$ & $1820 \pm 741$ & 2.6 \\
$\mathrm{~A} \beta_{1-40}$ & $6819 \pm 2436$ & $2678 \pm 811$ & 2.6 & & $13649 \pm 2838$ & $3927 \pm 1238$ & 3.7 \\
$\mathrm{~A} \beta_{1-42}$ & $1926 \pm 732$ & $550 \pm 168$ & 3.7 & & $4245 \pm 960$ & $991 \pm 321$ & 4.6 \\
\hline
\end{tabular}


a
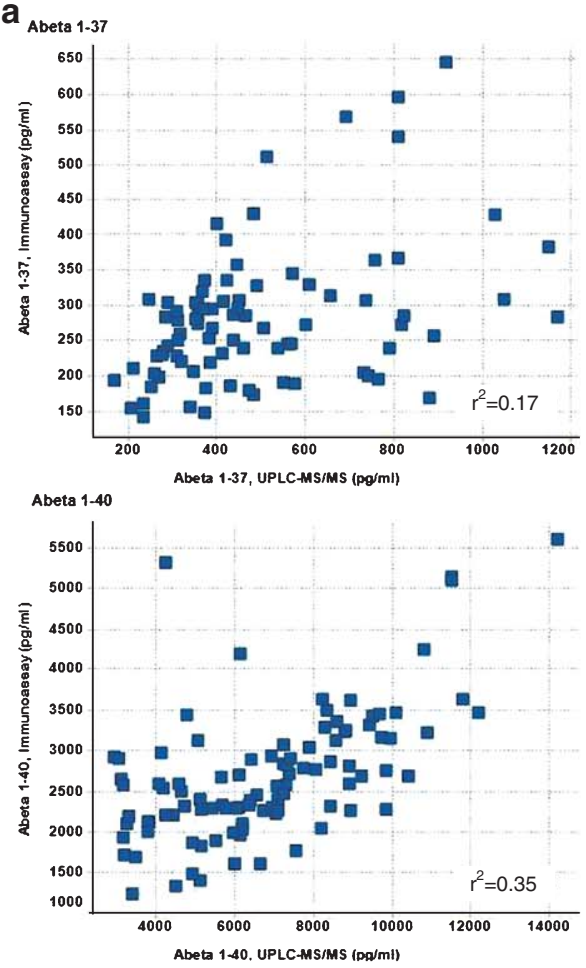

b
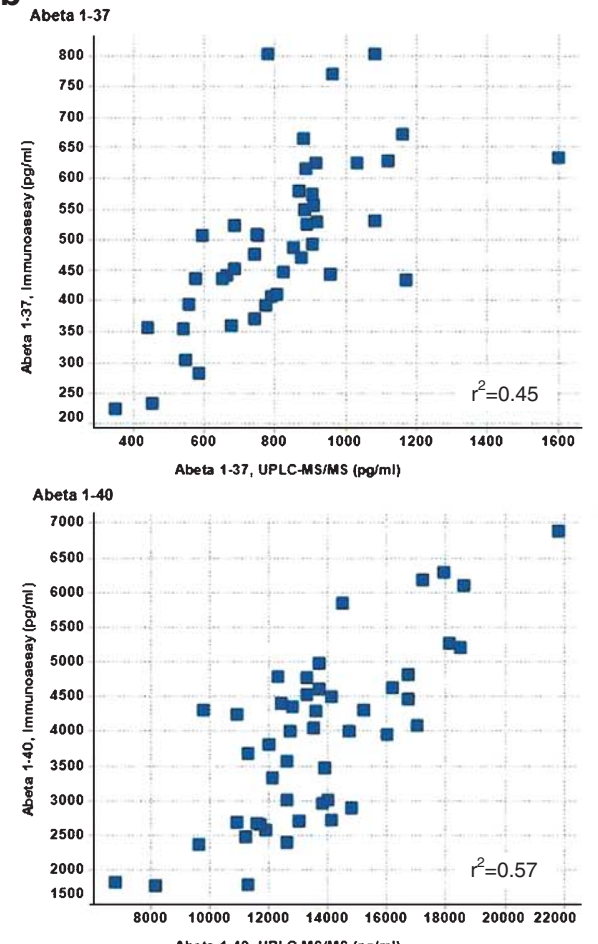
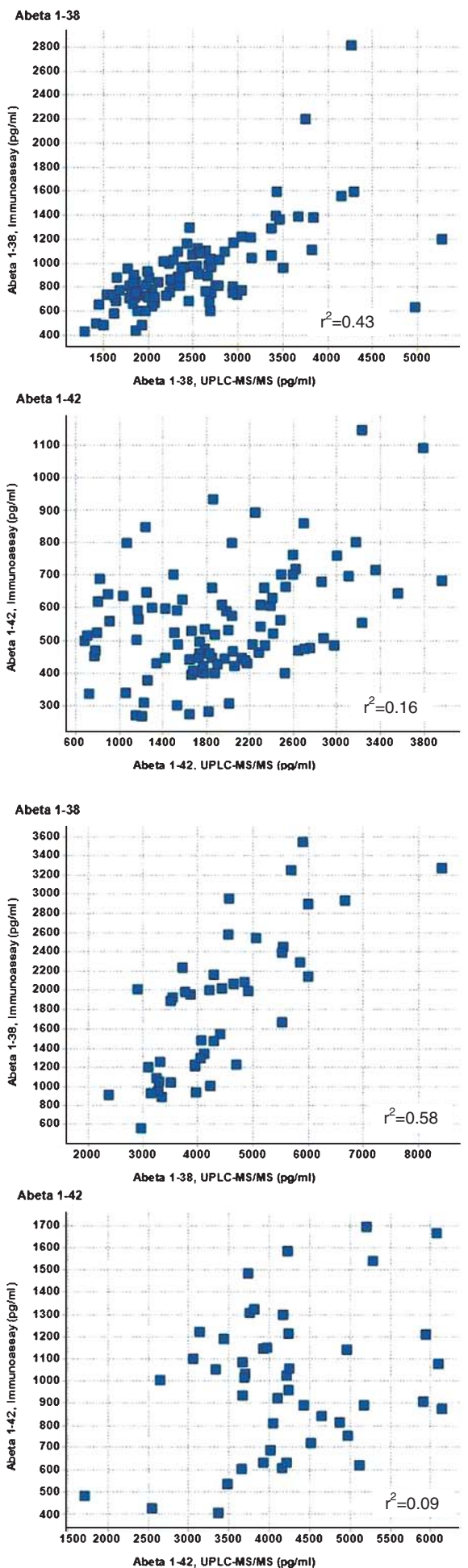

Fig. 1. Correlation between absolute baseline concentrations for A $\beta$ peptides in dog CSF measured with UPLC-MS/MS and Mesoscale immunoassay. $n=99$ for lateral ventricle (a) and 48 for cisterna magna (b). 
Table 2

Pharmacokinetic parameters for JNJ-B and JNJ-A after a single oral dose in dogs (mean \pm StDev; $n=4^{(1)}$ or $6^{(2)}$ )

\begin{tabular}{|c|c|c|c|c|c|c|}
\hline JNJ-A & & & & & & \\
\hline Dose & $\mathrm{mg} / \mathrm{kg}$ & $0.08^{(1)}$ & $0.16^{(1)}$ & $0.31^{(1)}$ & $2.5^{(1)}$ & $10^{(1)}$ \\
\hline $\mathrm{T}_{\max }$ & $\mathrm{h}$ & $4.5 \pm 2.5$ & $3.0 \pm 1.1$ & $4.5 \pm 2.5$ & $2.5 \pm 1.0$ & $2 \pm 0$ \\
\hline $\mathrm{C}_{\max }$ & $\mathrm{ng} / \mathrm{ml}$ & $13.2 \pm 4.3$ & $31.5 \pm 9.4$ & $85 \pm 43$ & $571 \pm 131$ & $1905 \pm 1057$ \\
\hline $\mathrm{T}_{1 / 2}$ & $\mathrm{~h}$ & $26 \pm 6.8$ & $26 \pm 3.2$ & $23 \pm 3$ & $25 \pm 4$ & $26 \pm 3$ \\
\hline $\mathrm{AUC}_{0 \text {-inf }}$ & ng.h/ml & $540 \pm 157$ & $1301 \pm 294$ & $3029 \pm 1378$ & $20203 \pm 4530$ & $72300 \pm 38779$ \\
\hline \multicolumn{7}{|l|}{ JNJ-B } \\
\hline Dose & $\mathrm{mg} / \mathrm{kg}$ & $1.25^{(2)}$ & $2.5^{(1)}$ & $5^{(2)}$ & $10^{(1)}$ & $20^{(2)}$ \\
\hline $\mathrm{T}_{\max }$ & $\mathrm{h}$ & $2.7 \pm 1.0$ & $2.3 \pm 1.3$ & $1.8 \pm 0.4$ & $1.8 \pm 0.5$ & $1.8 \pm 0.4$ \\
\hline $\mathrm{C}_{\max }$ & $\mathrm{ng} / \mathrm{ml}$ & $80.1 \pm 22.3$ & $152 \pm 35$ & $297 \pm 59$ & $756 \pm 282$ & $1460 \pm 204$ \\
\hline $\mathrm{T}_{1 / 2}$ & h & $5.6 \pm 1.1$ & $6.6 \pm 1.3$ & $4.7 \pm 1.2$ & $4.5 \pm 1.1$ & $6.1 \pm 0.9$ \\
\hline $\mathrm{AUC}_{0 \text {-inf }}$ & ng.h/ml & $779 \pm 216$ & $1632 \pm 407$ & $2344 \pm 623$ & $5178 \pm 1708$ & $14207 \pm 2588$ \\
\hline
\end{tabular}

respectively. Especially with the small sample size per group, mean changes within $20 \%$ from baseline at any time point were not considered relevant since this often seen in vehicle groups and could be due to intra-individual variability. Both compounds lowered all four $A \beta$-isoforms in a dose related way. The data were in line for both assays for $A \beta_{1-37}, A \beta_{1-38}$ and $A \beta_{1-40}$. There was a discrepancy in $A \beta_{1-42}$ changes between the UPLC-MS/MS and Mesoscale for JNJ-B at the dose of $2.5,5$, and $10 \mathrm{mg} / \mathrm{kg}$ and for JNJ-A at the dose of $0.16,0.31$, and $2.5 \mathrm{mg} / \mathrm{kg}$. With UPLC$\mathrm{MS} / \mathrm{MS}$, differences with baseline were in general smaller and within the range of the vehicle.

\section{PK/PD analysis}

The plasma concentrations needed for a $50 \%$ lowering of $\mathrm{A} \beta$ in $\mathrm{CSF}$ are listed in Table 3. Based on the Mesoscale data, $\mathrm{EC}_{50}$ values were around $20 \mathrm{ng} / \mathrm{ml}$ for JNJ-A and 130-160 ng/ml for JNJ-B. The $\mathrm{EC}_{50}$ values based on the UPLC-MS/MS for $A \beta_{1-38}$ and $A \beta_{1-40}$ were in general slightly higher, however, within acceptable range of the mesoscale based values. The discrepancy between UPLC-MS/MS and mesoscale for $A \beta_{1-42}$ resulted in a higher estimated UPLCMS/MS based $\mathrm{EC}_{50}$ for compound $\mathrm{A}$.

No $\mathrm{EC}_{50}$ was calculated for $\mathrm{A} \beta_{1-37}$ since values were just above the lowest limit of quantification, resulting sometimes in a large variability between duplicates in the Mesoscale assay, which did not allow a reliable estimate.

\section{DISCUSSION}

Baseline $\mathrm{A} \beta$ concentrations in dog CSF were in general two times higher in CSF sampled from the cisterna magna than in CSF sampled from the lateral ventricle. CSF originates from a number of sites: the choroid plexus of the lateral, third and fourth ventricles, directly from the brain by way of the ependymal lining of the ventricular system, and via the pial-glial membrane covering its external surface and from blood vessels in the pia-arachnoid. $35 \%$ of the CSF derives from the third and lateral ventricles, $23 \%$ from the fourth ventricle, and $42 \%$ from the subarachnoid space [20]. The CSF flows from the lateral ventricle into the third ventricle and then via the aqueduct into the fourth ventricle. From the fourth ventricle, CSF flows into the cisterna magna (cerebellomedullary cistern) of the subarachnoid space through the medial foramen and the two lateral foramina. The only functional communication between the cerebral ventricles and the subarachnoid spaces is in the fourth ventricle [21]. The sources of $A \beta$ in CSF remain to be fully elucidated; however, drainage from the brain seems to be the major origin since changes in CSF A $\beta$ levels reflect changes in brain $A \beta$ following therapeutic treatments [11]. The choroid plexus plays a major role in removing $A \beta$ from the CSF by way of metabolism of $A \beta$ [22] and efflux from the CSF to the blood [23]. The higher concentrations of the $A \beta$ concentrations in the cisterna magna could therefore be a result of a higher excretion of brain $A \beta$ at the subarachnoid side than at the ventricular side and/or a fast uptake of $A \beta$ from the CSF via the choroid plexus in the lateral ventricle.

Free $A \beta$ peptides in CSF and not self-aggregated $A \beta$ peptides and $A \beta$ peptides bound to matrix proteins are exposed to antibodies used for measurements in immunoassays and probably detected with immunoassays like the Mesoscale technology [15]. Acetonitrile, an organic solvent, is added to the CSF sample for UPLC-MS/MS [13]. Thus, bound A $\beta$ peptides could be partially dissolved and free as well as bound $A \beta$ peptides after dissolution are measured. As a consequence, consistently higher A $\beta$ concentrations were measured with the UPLC-MS/MS compared with the 
$\mathbf{a}$

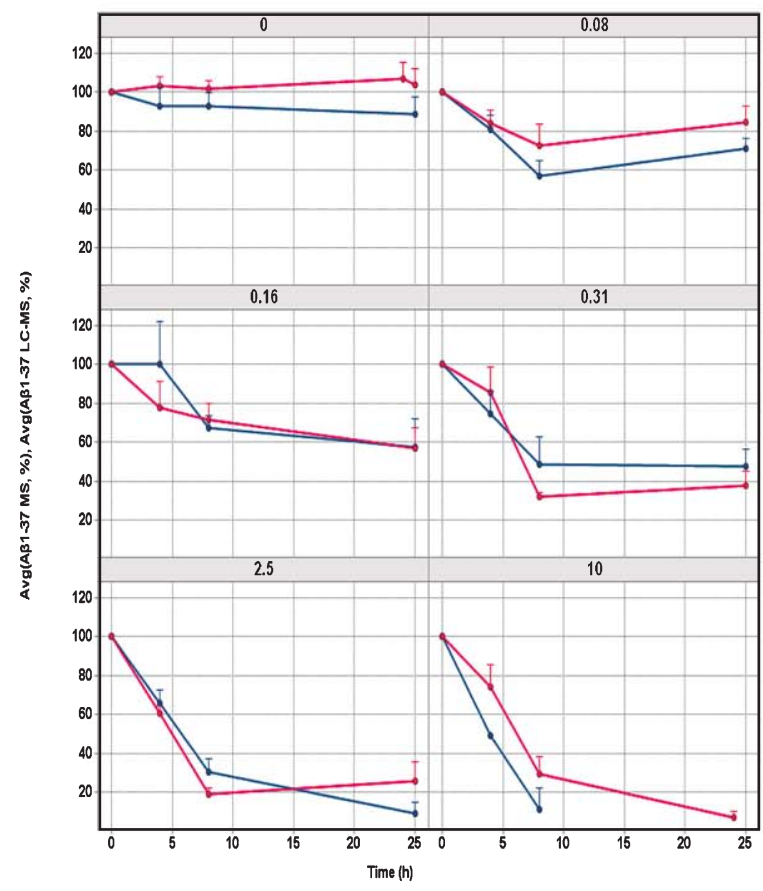

c

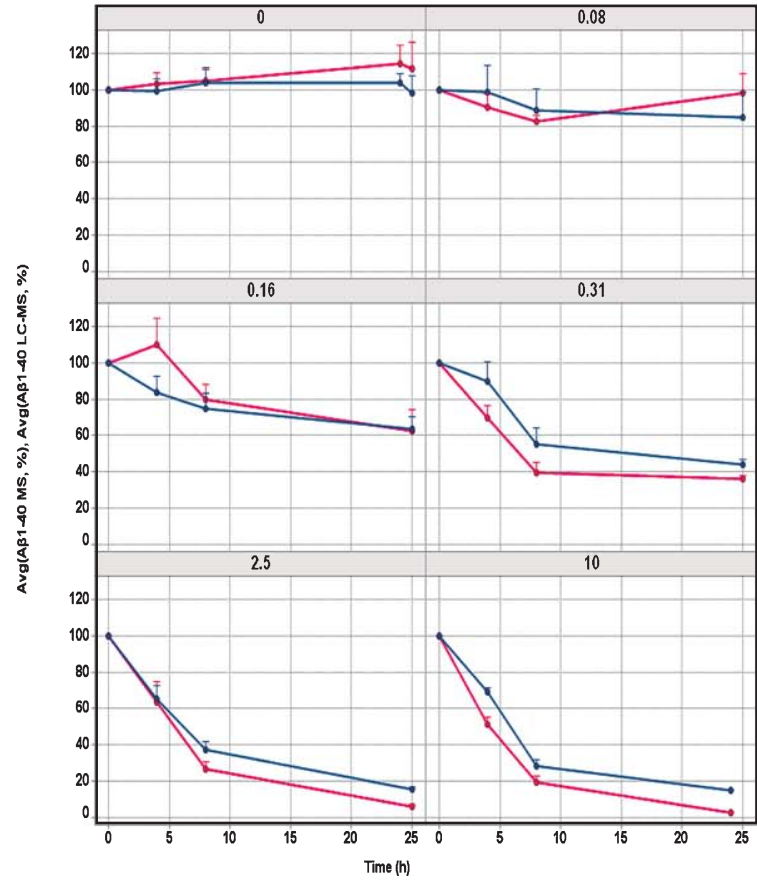

b

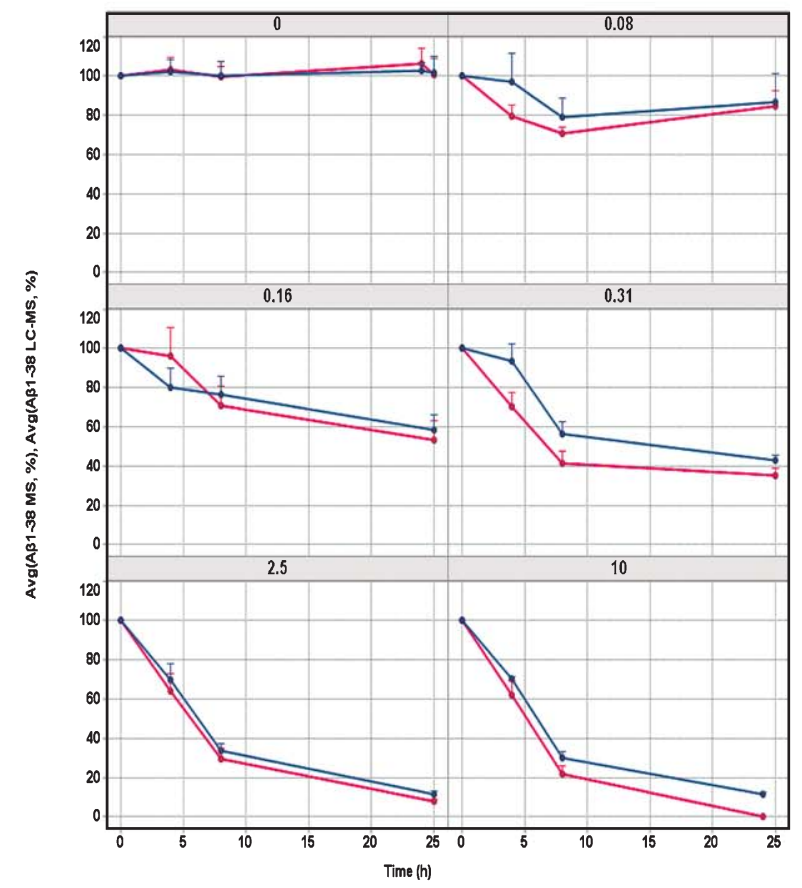

d

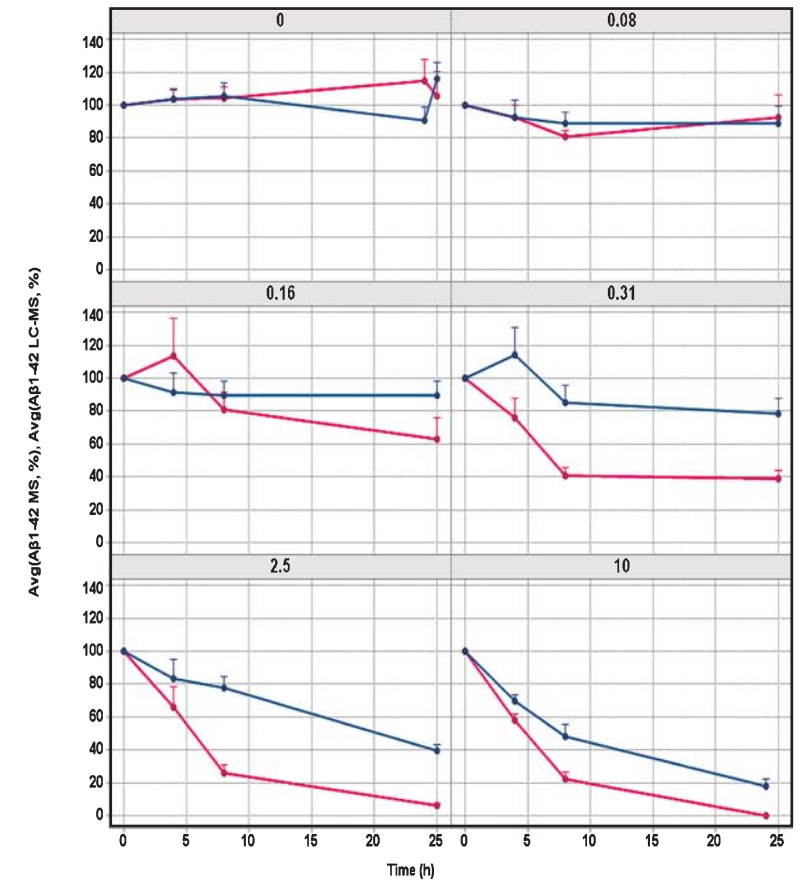

Fig. 2. Changes (\% from baseline) in A $\beta$ levels in CSF (lateral ventricle) after dosing JNJ-A at $0,0.08,0.16,0.31,2.5$, and $10 \mathrm{mg} / \mathrm{kg}$ : comparison of UPLC-MS/MS (blue line) and Mesoscale immunoassay (red line) for $\mathrm{A} \beta_{1-37}$ (a), $\mathrm{A} \beta_{1-38}$ (b), $\mathrm{A} \beta_{1-40}$ (c) and $\mathrm{A} \beta_{1-42}$ (d) (mean $\left.+\mathrm{SEM}, n=4\right)$. 
a

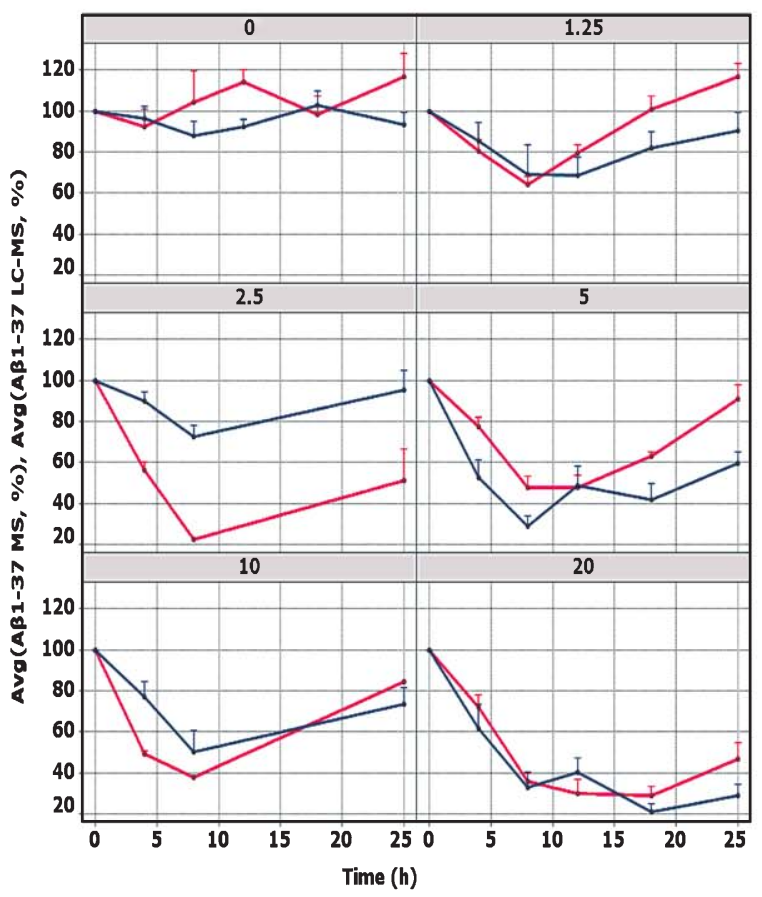

c

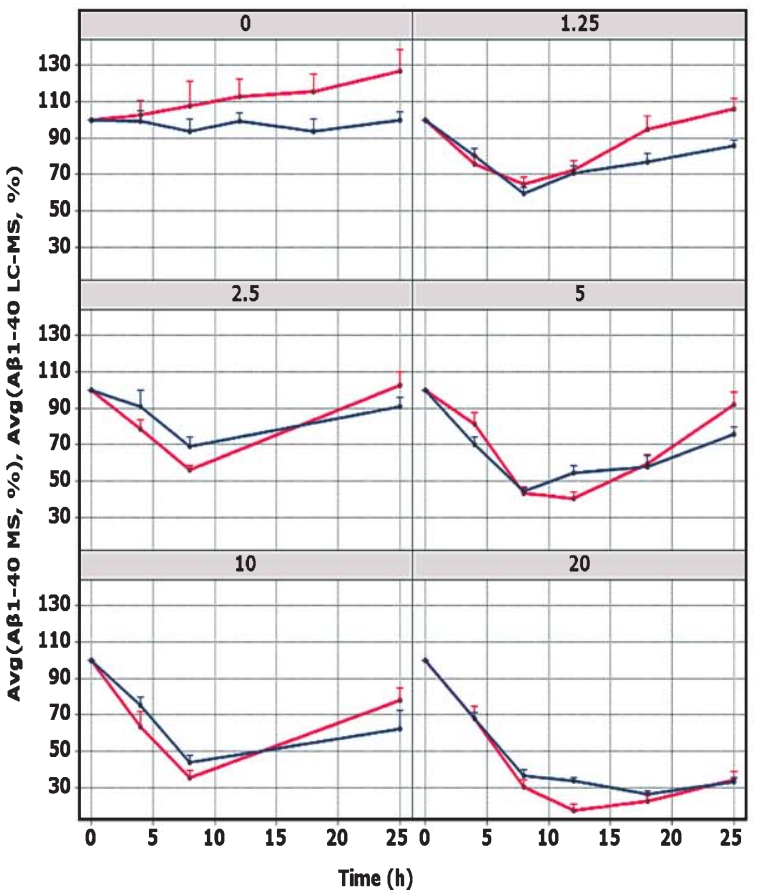

b

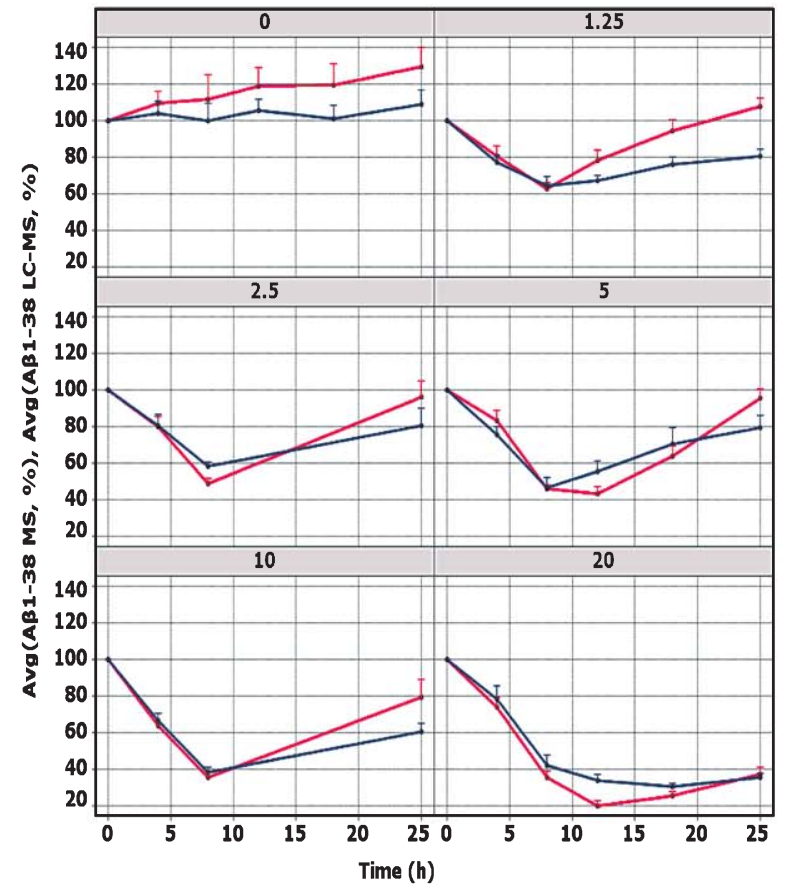

d

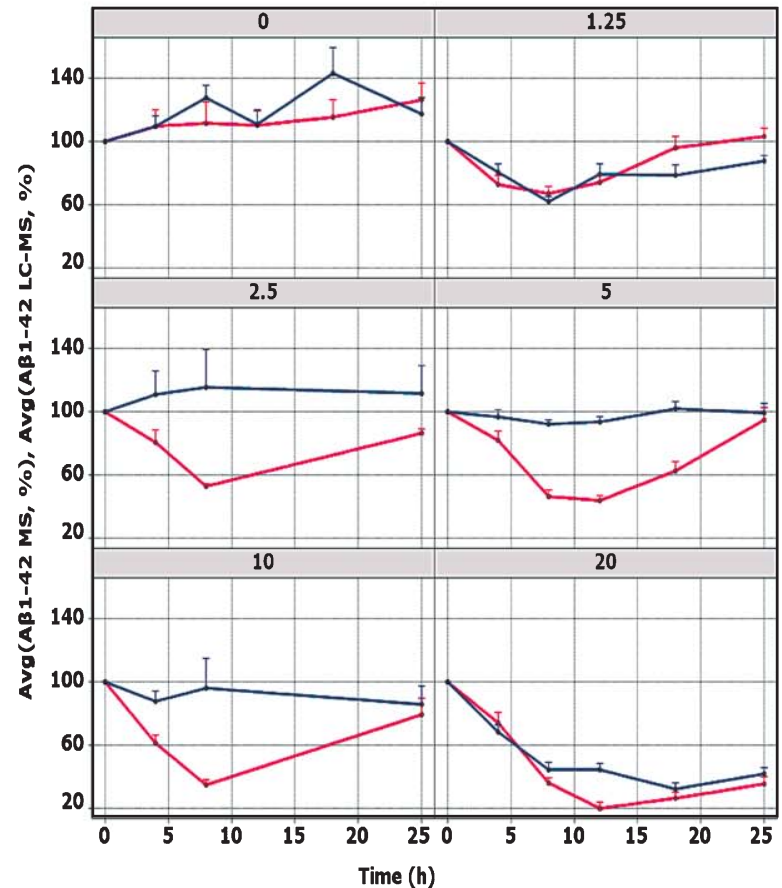

Fig. 3. Changes (\% from baseline) in A $\beta$ levels in CSF (lateral ventricle) after dosing JNJ-B at $0,1.25,2.5,5,10$, and $20 \mathrm{mg} / \mathrm{kg}$ : comparison of UPLC-MS/MS (blue line) and Mesoscale immunoassay (red line) for $A \beta_{1-37}$ (a), $A \beta_{1-38}(\mathrm{~b}), A \beta_{1-40}(\mathrm{c})$ and $A \beta_{1-42}(\mathrm{~d})(\mathrm{mean}+\mathrm{SEM}, n=4$ for 2.5 and $10 \mathrm{mg} / \mathrm{kg}$ and $n=6$ for $1.25,5$ and $20 \mathrm{mg} / \mathrm{kg}$ ). 
Table 3

Plasma level of test compounds $(\mathrm{ng} / \mathrm{ml})$ required for a $50 \%$ lowering of $\mathrm{A} \beta$ in $\mathrm{CSF}\left(\mathrm{EC}_{50}\right)$ for $\mathrm{A} \beta_{1-38}, \mathrm{~A} \beta_{1-40}$ and $\mathrm{A} \beta_{1-42}$ when measured with UPLC-MS/MS or Mesoscale

\begin{tabular}{llccc}
\hline Compound & Assay & $\mathrm{A} \beta_{1-38}$ & $\mathrm{~A} \beta_{1-40}$ & $\mathrm{~A} \beta_{1-42}$ \\
\hline JNJ-A & UPLC-MS/MS & 24 & 28 & 68 \\
& Mesoscale & 19 & 19 & 19 \\
JNJ-B & UPLC-MS/MS & 209 & 230 & 219 \\
& Mesoscale & 130 & 151 & 162 \\
\hline
\end{tabular}

Mesoscale. $A \beta_{1-42}$ has a higher affinity to aggregate than $A \beta_{1-40}$ [24] and can also bind to other proteins in the CSF [15]. This tendency could explain the higher UPLC-MS/MS/Mesoscale ratio for $A \beta_{1-42}$ compared to the smaller peptides. The higher tendency for $\mathrm{A} \beta_{1-42}$ to bind and aggregate increases variability in measured concentrations $[15,25]$. This is reflected in a low correlation between the concentrations measured with both assays for $A \beta_{1-42}$, while a higher correlation is seen for $A \beta_{1-38}$ and $A \beta_{1-40}$. The variable correlation between both assays for $A \beta_{1-37}$ could be coincidental and a consequence of the low concentrations for $\mathrm{A} \beta_{1-37}$, which were around the lowest detection limit. However, whether aggregation is present in incurred samples or introducing post-sampling is also not clear. No additional data are currently available to support the aggregation hypothesis.

The aim of the model is to show acute target engagement of BACE inhibitors at an early stage in drug development and estimate an $\mathrm{EC}_{50}$ for lowering $\mathrm{A} \beta$ peptides. Young to middle-aged animals are used for this purpose. To address the effect of BACE inhibitors in a more diseased state, older dogs, which show decreased $A \beta_{1-42}$ levels in CSF as in humans [6], could be used.

BACE inhibition results in lowering of $\mathrm{A} \beta$ peptides in CSF [26]. Both JNJ-B and JNJ-A dose-dependently lowered $A \beta$ peptides in CSF. In the present studies, CSF was sampled from the lateral ventricle, however, similar drug effects can also be seen in CSF sampled from the cisterna magna. We prefer sampling from the lateral ventricle in awake animals, since dogs need to be anesthetized when CSF is sampled from the cisterna magna. The lowering of $A \beta$ peptides was detected with the Mesoscale as well as the UPLC-MS/MS assay. The aberrant $\mathrm{EC}_{50}$ for lowering $\mathrm{A} \beta_{1-42}$ measured with the UPLC-MS/MS when compared to the other $\mathrm{EC}_{50}$ values for one of the compounds results from the limited change with baseline, which was seen at certain doses and which was not in line with changes seen in the other peptides with UPLC-MS/MS and the changes seen with Mesoscale. One hypothesis is that this discrep- ancy results from an additional variability introduced by a variable dissolution of $A \beta_{1-42}$ after adding acetonitrile to the samples for UPLC-MS/MS analysis, which could mask the effect of a compound.

\section{CONCLUSION}

Both Mesoscale and UPLC-MS/MS can be used for measuring $A \beta$ peptides in CSF in the evaluation of $A \beta$ lowering effects of BACE inhibitors. Care must be taken when only $A \beta_{1-42}$ is measured. Druginduced lowering of $A \beta_{1-42}$ can be missed with the UPLC-MS/MS assay. A hypothesis is that adding an organic solvent as acetonitrile in the UPLC-MS/MS assay results in a variable dissolution of aggregated and bound $A \beta$ peptides, which could mask the effect of a drug. The importance of the dissolution is higher for the $\mathrm{A} \beta_{1-42}$ peptide, which is more prone to aggregate and bind to proteins in CSF. However, additional studies are needed to support this hypothesis.

\section{DISCLOSURE STATEMENT}

Authors' disclosures available online (http://www.jalz.com/disclosures/view.php?id=1833).

\section{REFERENCES}

[1] Nelson PT, Braak H, Markesbery WR (2009) Neuropathology and cognitive impairment in Alzheimer disease: A complex but coherent relationship. J Neuropathol Exp Neurol 68, 1-14.

[2] Bitan G, Kirkitadze MD, Lomakin A, Vollers SS, Benedek GB, Teplow DB (2003) Amyloid beta-protein (A $\beta$ ) assembly: $\mathrm{A} \beta 40$ and $\mathrm{A} \beta 42$ oligomerize through distinct pathways. Proc Natl Acad Sci U S A 100, 330-335.

[3] Cole SL, Vassar R (2008) The role of amyloid precursor protein processing by BACE1, the $\beta$-secretase, in Alzheimer disease pathophysiology. J Biol Chem 283, 29621-29625.

[4] Karran E, Mercken M, De Strooper B (2011) The amyloid cascade hypothesis for Alzheimer's disease: An appraisal for the development of therapeutics. Nat Rev Drug Discov 10, 698-712.

[5] Borghys H, Tuefferd M, Van Broeck B, Clessens E, Dillen L, Cools W, Vinken P, Straetemans R, De Ridder F, Gijsen H, Mercken M (2012) A canine model to evaluate efficacy and safety of $\gamma$-secretase inhibitors and modulators. J Alzheimers Dis 28, 809-822.

[6] Head E, Pop V, Sarsoza F, Kayed R, Beckett TL, Studzinski CM, Tomi JL, Glabe CG, Murphy MP (2010) Amyloid $\beta$ peptide and oligomers in the brain and CSF of aged canines. J Alzheimers Dis 20, 637-646.

[7] Cotman CW, Head E (2008) The canine (dog) model of human aging and disease: Dietary, environmental and immunotherapy approaches. J Alzheimers Dis 15, 685-707.

[8] Studzinski CM, Araujo JA, Milgram NW (2005) The canine model of human cognitive aging and dementia: 
Pharmacological validity of the model for assessment of human cognitive-enhancing drugs. Prog Neuropsychopharmacol Biol Psychiatry 29, 489-498.

[9] Sarasa L, Gallego C, Monleon I, Olvera A, Canudas J, Montanes M, Pesini P, Sarasa M (2010) Cloning, sequencing and expression in the dog of the main amyloid precursor protein isoforms and some of the enzymes related with their processing. Neuroscience 171, 1091-1101.

[10] Portelius E, Van Broeck B, Andreasson U, Gustavsson MK, Mercken M, Zetterberg H, Borghys H, Blennow K (2010) Acute effect on the $A \beta$ isoform pattern in CSF in response to $\gamma$-secretase modulator and inhibitor treatment in dogs. $J$ Alzheimers Dis 21, 1005-1012.

[11] Lu Y, Barton HA, Leung L, Zhang L, Hajos-Korcsok E, Nolan CE, Liu J, Becker SL, Wood KM, Robshaw AE, Taylor CK, O'Neill BT, Brodney MA, Riddel D (2013) Cerebrospinal fluid $\beta$-amyloid turnover in the mouse, dog, monkey and human evaluated by systematic quantitative analyses. $\mathrm{Neu}$ rodegener Dis 12, 36-50.

[12] Bjerke M, Portelius E, Minthon L, Wallin A, Anckarsäter H, Anckarsäter R, Andreasen N, Zetterberg H, Andreasson U, Blennow K (2010) Confounding factors influencing amyloid beta concentration in cerebrospinal fluid. Int J Alzheimers Dis 2010, pii: 986310.

[13] Dillen L, Cools W, Vereyken L, Timmerman P (2011) A screening UPLC-MS/MS method for the analysis of amyloid peptides in cerebrospinal fluid of preclinical species. Bioanalysis 3, 45-55.

[14] Goda R, Kobayashi N (2012) Evaluation of peptide adsorption-controlled liquid chromatography-tandem mass spectrometric (PAC-LC-MS/MS) method for simple and simultaneous quantitation of amyloid beta 1-38, 1-40, 1-42 and 1-43 peptides in dog cerebrospinal fluid. J Chromatogr B Analyt Technol Biomed Life Sci 895-896, 137-145.

[15] Slemmon JR, Meredith J, Guss V, Anreasson U, Andreasen $\mathrm{N}$, Zetterberg H, Blennow K (2011) Measurement of A $\beta 1-42$ in cerebrospinal fluid is influenced by matrix effects. $J \mathrm{Neu}$ rochem 120, 325-333.

[16] Dhuyvetter D, Borghys H, Van Broeck B, Dillen L, Gijsen H, Jacobs T, Steckler T (2012) Evaluation and comparison of BACE-1-inhibitors in a canine PK/PD model. Soc Neurosci Abstr, Poster \#343.08/G17.
[17] Trabanco-Suarez A, Rombouts F, Tresaderm G, Van Gool M, Macdonald G, Martinez Lamenca C, Gijsen H (2011) Preparation of 5,6-dihydro-2H-[1,4] oxazin-3-yl-amine derivatives useful as therapeutic inhibitors of $\beta$-secretase (BACE). PCT Int Appl, WO 2011-154431.

[18] Wilsson-Rahmber M, Olovson SG, Forshult E (1998) Method for long-term cerebrospinal fluid collection in the conscious dog. J Invest Surg 11, 207-214.

[19] Gabrielson J, Weiner D (2001) Pharmacokinetic and Pharmacodynamic Data Analysis: Concepts and Applications, Swedish Pharmaceutical Press, Stockholm.

[20] de Lahunta A (1977) Veterinary Neuroanatomy and Clinical Neurology, Saunders, St. Louis.

[21] Battal B, Kocaoglu M, Bulakbasi N, Husmen G, Tuba Sanal $\mathrm{H}$, Tayfun $\mathrm{C}$ (2011) Cerebrospinal fluid flow imaging by using phase-contrast MR technique. Br J Radiol 84, 758-765.

[22] Crossgrove JS, Smith EL, Zheng W (2007) Macromolecules involved in production and metabolism of beta-amyloid at the brain barriers. Brain Res 1138, 187-195.

[23] Crossgrove J, Li JG, Zheng W (2005) The choroid plexus removes $\beta$-amyloid from brain cerebrospinal fluid. Exp Biol Med 230, 771-776.

[24] Finder VH, Glockshuber R (2007) Amyloid- $\beta$ aggregation. Neurodegener Dis 4, 13-27.

[25] Pannee J, Portelius E, Oppermann M, Atkins A, Hornshaw M, Zegers I, Höjrup P, Minthon L, Hansson O, Zetterberg H, Blennow K, Gobom J (2013) A selected reaction monitoring (SRM)-based method for absolute quantification of $A \beta 38$, $A \beta 40$ and $A \beta 42$ in cerebrospinal fluid of Alzheimer's disease patients and healthy controls. JAlzheimers Dis 33, 1021-1032.

[26] Sankaranarayanan S, Holahan MA, Colussi D, Crouthamel MC, Devanarayan V, Ellis J, Espeseth A, Gates AT, Graham SL, Gregro AR, Hazuda D, Hochman JH, Holloway K, Jin L, Kahana J, Lai MT, Lineberger J, McGaughey G, Moore KP, Nantermet P, Pietrak B, Price EA, Rajapakse H, Stauffer S, Steinbeiser MA, Seabrook G, Selnick HG, Shi XP, Stanton MG, Swestock J, Tugusheva K, Tyler KX, Vacca JP, Wong J, Wu G, Xu M, Cook JJ, Simon AJ (2009) First demonstration of cerebrospinal fluid and plasma A beta lowering with oral administration of a beta-site amyloid precursor protein-cleaving enzyme 1 inhibitor in nonhuman primates. J Pharmacol Exp Ther 328, 131-140. 